\title{
Chemical Composition and Antibacterial Activity of Essential Oils from Struchium sparganophora Linn. Ktze Asteraceae
}

\author{
Lateef S. Kasim*, Kafayat O. Olaleye, A. B. Fagbohun, S. F. Ibitoye, O. E. Adejumo \\ Department of Pharmaceutical and Medicinal Chemistry, Olabisi Onabanjo University, Sagamu, Nigeria \\ Email: ${ }^{*}$ kasimls@yahoo.co.uk
}

Received 25 April 2014; revised 30 May 2014; accepted 7 June 2014

Copyright (C) 2014 by authors and Scientific Research Publishing Inc.

This work is licensed under the Creative Commons Attribution International License (CC BY).

http://creativecommons.org/licenses/by/4.0/

c) (i) Open Access

\begin{abstract}
Struchium sparganophora Linn. Ktze Asteraceae is a culinary herb that is consumed in the Western part of Nigeria and has wide medicinal uses in traditional medicine. The present study was carried out to determine the chemical composition of the oils from its leaf and stem and their antibacterial activity. Essential oils were collected from the leaf and stem of Struchium sparganophora by hydrodistillation and analysed by GC and GC-MS. The antimicrobial activity was tested against Gram negative ( $G$ - ve) and Gram positive ( + ve) microorganisms obtained from the Medical Microbiology Unit, University College Hospital (UCH), Ibadan, Nigeria. Forty-six compounds were identified in the leaf representing $\mathbf{9 5 . 3 \%}$ of the total oil while fifty-five compounds were identified in the stem representing $93.5 \%$ of the oil. $\beta$-caryophyllene, Germacrene A, a-humulene and Germacrene D represented the major components in both oils. Antibacterial activity of the oils against certain strains of bacteria showed that the different concentrations of the oils $(100-10,000 \mathrm{ppm})$ from the leaf had activity ranging from $9.0 \pm 1.0$ to $14.3 \pm 2.55 \mathrm{~mm}$ while that from the stem had activity ranging from $18.5 \pm 2.2$ to $20.0 \pm 0.0 \mathrm{~mm}$ for both $\mathrm{G}-\mathrm{ve}$ and $\mathrm{G}+\mathrm{ve} \mathrm{mi}-$ croorganisms respectively.
\end{abstract}

\section{Keywords}

Essential Oils, $\beta$-Caryophyllene, Germacrene A, Antibacterial Activity

\section{Introduction}

Plants have been an indispensable part of human lives either as source of food, shelter, ecological conservation and most importantly avenue for the discovery and synthesis of drugs. The use of ethno-botanical information

\footnotetext{
${ }^{*}$ Corresponding author.
}

How to cite this paper: Kasim, L.S., Olaleye, K.O., Fagbohun, A.B., Ibitoye, S.F. and Adejumo, O.E. (2014) Chemical Composition and Antibacterial Activity of Essential Oils from Struchium sparganophora Linn. Ktze Asteraceae. Advances in Biological Chemistry, 4, 246-252. http://dx.doi.org/10.4236/abc.2014.44030 
about different plants have greatly enhanced plant research [1] and thus now provide the model for more than $50 \%$ of Western drugs [2]. Essential oils from plants have been in the forefront of tremendous breakthrough in the classification and production of products with therapeutic properties.

Struchium sparganophora is a culinary herb in most African countries. There is a severe lack of relevant scientific research carried out on this herb, despite its wide spread consumption in African countries and its ethnobotanical use. Natural products from plant origin have been a source of many novel drugs in conventional use in Health care today e.g. Artemisinin isolated from the plant Artemisia annua, sweet wormwood, a herb employed in Chinese traditional medicine and taxol from Taxus brevifola [3]. At the same time, the use of traditional medicines has increased as consumers seek complementary and or alternatives to prescribed drugs.

Plants belonging to the family Asteraceae constitute one of the largest plant families. It contains over 40 economically important species; they are used as food (lettuce and Jerusalem artichopa), oil (Sun flowers and afflower), medicine (chamomile) and many as an ornamental plant [4].

Struchium sprganophora is a culinary herb in Nigeria. The leaves are boiled in water drained completely and added to soup or consumed as a vegetable. It is also widely used medicinally in a number of countries: decoction of the stem and root are employed in the treatment of headaches, gonorrhea [5]. The plant is an antidote for poisons [6]. In Gulf of Guinea, it is used as anti-malaria [7] while it also has anti measles activities [4]. The leaves posses nutritive, antioxidant, antimicrobial and the antimalaria activities [8] and also the anti-oxidant properties of its polar and non polar leaf extracts have been reported [9]. Phytochemical composition of the leaf and the isolation of sesquiterpine lactone, luteolin, vernodalin, 3 methyl, 2, 6 hexacosedienol from it have been reported [10]-[12].

The objective of this study was to determine the chemical composition of the essential oils from the leaf and stem of Struchium sparganophora and their antibacterial activity.

\section{Materials and Methods.}

\subsection{Plant Material}

Fresh aerial parts of Struchiun sparganophora were collected during full flowering season at the riverbed in Asejire, Oyo state. It was identified and authenticated at the Federal Research Institute of Nigeria (FRIN) by Mr. Micheal by comparing with Voucher specimens 105358 and a specimen kept.

\subsection{Isolation of Essential Oil}

Fresh leaves and stems $108 \mathrm{~g}$ and $270 \mathrm{~g}$ were weighed respectively and hydrodistilled using a Clevenger-type apparatus. The oils gotten were dried over anhydrous Sodium sulphate and stored in vials at low temperature until analysis.

\subsection{GC Analysis}

The essential oils were subjected to GC-FID analysis carried out on an Agilent model 6890 gas chromatograph fitted with a flame ionization detector. Fused silica capillary Agilent tech HS-5ms column $(30 \times 0.25 \mathrm{~mm}, 0.25$ um film thickness) was used for the separation. Helium was used as carrier gas at flow rate of $1 \mathrm{ml} / \mathrm{min}$. GC oven temperature was programmed at $60^{\circ} \mathrm{C}$ (held for 2 minutes) and raised to $240^{\circ} \mathrm{C}$ at a rate of $4^{\circ} \mathrm{C} / \mathrm{min}$ with final hold time of 20 minutes. Injection and detection temperature was set at $200^{\circ} \mathrm{C}$ and $250^{\circ} \mathrm{C}$ respectively.

\subsection{GC-MS Analysis}

The GC-MS spectroscopy was performed on an Agilent model 6890 instrument with split/spilt less injection interfaced to a 5973 mass selective detector operated at $70 \mathrm{eV}$ with a mass range of $\mathrm{m} / \mathrm{z} 50-500$. Oven temperature was programmed from $60^{\circ} \mathrm{C}-230^{\circ} \mathrm{C}$ at a rate of $3^{\circ} \mathrm{C} / \mathrm{min}$ with injector temperature $200^{\circ} \mathrm{C}$ and detector temperature of $250^{\circ} \mathrm{C}$. The volume injected was $1 \mu \mathrm{L}$, split ratio $1: 60$; nitrogen was used as carrier gas at 1 $\mathrm{mL} / \mathrm{min}$.

\subsection{Identification of Constituents}

Identification of individual constituent of the oils was achieved based on their linear retention indices (LRI) after co-injection of the sample with homologous series of normal alkane by comparison of the masses (MS) with 
those reported in NIST 05 and Wiley libraries and those published in literature [13].

\subsection{Microorganisms and Media}

\subsubsection{Preparation of Test Organisms}

The microorganisms used in this study were Salmonella typhi, Bacillus cereus, Proteus mirabilis, Pseudomonas aeruginosa and Bacillus subtilis (Table 1). They were obtained from the Medical Microbiology Unit, University College Hospital (UCH), Ibadan, Nigeria and were subsequently maintained as stock stains.

\subsubsection{Preparation of Culture Media}

Mueller Hinton agar (Becton Dickinson ${ }^{\circledR}$ M.D USA) was used for direct sensitivity testing for the bacteria while sabouraud extract broth was used for the fungus. $16 \mathrm{~g}$ of powder was dissolved in $400 \mathrm{ml}$ distilled water and shaken until it was evenly dispersed. It was then sterilized in the autoclave at $121^{\circ} \mathrm{C}$ for 15 minutes. $60 \mathrm{~g}$ sabouraud dextrose agar powder was mixed with 1 litre distilled water until evenly dispersed. It was then heated up with repeated stirring and boiling for complete dissolution $0.20 \mathrm{ml}$ solution was then transferred into universal bottles while hot and then sterilized in the autoclave at $121^{\circ} \mathrm{C}$ for 15 minutes. Nutrient broth was prepared thus: $13 \mathrm{~g}$ of powder was dissolved in 1 liter of distilled water and dispersed. Then $5 \mathrm{ml}$ of the solution was transferred into bottles and sterilized at $121^{\circ} \mathrm{C}$ for 15 minutes.

\subsubsection{Agar-Well Diffusion Assay}

Agar-well diffusion method by Durodola, 1977 [14] and Cheruiyot et al., 2009 [15] was used for this microbiological assay.

A concentrations of (100 - 10.000) ppm of the essential oils was prepared from the stock solution. Cultures of Salmonella typhi, Bacillus cereus, Proteus mirabilis, Pseudomonas aeruginosa and Bacillus subtilis were inoculated separately on the surface of Mueller Hinton agar plates by surface spreading using a sterile cotton swab and each bacterium evenly spread over the entire surface of agar plate to obtain a uniform inoculum. The sensitivity testing of the oils was done using the agar well diffusion method [16] whereby, wells of $6 \mathrm{~mm}$ diameter and $5 \mathrm{~mm}$ depth were made on the solid agar using a sterile glass borer and Gentamicin (Sigma, UK) $(10 \mu \mathrm{g} / \mathrm{ml}$ ) in distilled water was used as a positive control. Distilled water was used as negative control. All the tests were ran in triplicates for quality results. The set up was incubated for $24 \mathrm{hr}$ at $37^{\circ} \mathrm{C}$ for anti-microbial test and the zones of inhibition were measured using a ruler $\left(\mathrm{AIM}^{\mathbb{B}}\right)$ and a pair of divider, and then results reported in millimeters (mm). The inhibition was measured as a basis for activity [17].

\section{Results and Discussions}

Hydrodistillation of essential oil from leaf and stem of Struchium sparganophora gave a colourless liquid with characteristic smell of a yield of $0.15 \pm 0.0 \% \mathrm{w} / \mathrm{w}$ and $0.08 \pm 0.01 \% \mathrm{w} / \mathrm{w}$ respectively

The GC and GC/MS analysis of these oils resulted in the identification of 46 compounds in the leaf representing $95.3 \%$ of the oils while 55 compounds were identified in the stem representing $93.5 \%$ of the total oil as shown in Table 2.

Major constituents of the essential oil from the leaf were $\beta$-caryophyllene (44.5\%), humulene (5.6\%), Caryophyllene oxide (4.2\%), Germacrene A (3.4\%) and Germacrene D (2.9\%) indicating that sesquiteterpene hydrocarbon represented $61.2 \%$ of total oil.

In the stem, the major compounds were $\beta$-caryophyllene (26.1\%), Caryophyllene oxide (4.9\%), Humulene (4.2\%), and Selinene (2.4\%). This also indicated that sesquiterpene hydrocarbon accounted for $37.1 \%$ of its total oil. There was appreciable presence of methylsalicylate in both oils.

Oils from the leaf of same family Astereacea showed similarity in some type of compounds present in them but at different concentrations e.g. Vernonia scorpiodes, Vernonia migeodi and Vernonia perrotetti had $\beta$-caryophyllene and Germacrene D as part of their major constituents [18]. Comparing the oils from Struchium sparganophora with those from some members in the Asteraceae family showed they have at least two of these compounds in common. Germacrene D, $\beta$-caryophyllene and 1,8-cineole [19]-[21].

Table 3 and Table 4 showed the result of the antibacteria assay. The essential oil from the leaf had activity against the strains as indicated by their inhibition zones. The essential oil from the stem had the highest activity 
Table 1. List of the test organisms used.

\begin{tabular}{|c|c|c|}
\hline \multicolumn{2}{|c|}{ Microorganism } & Description \\
\hline \multicolumn{2}{|c|}{ Salmonella typhi } & UCH NO12 Gram negative bacilli \\
\hline Bacillus & cereus & UCH PO13 Gram positive cocci \\
\hline Proteus & mirabilis & UCH NO13 Gram negative bacilli \\
\hline \multicolumn{2}{|c|}{ Pseudomonas aeruginosa } & UCH NO14 Gram negative bacilli \\
\hline \multicolumn{2}{|c|}{ Bacillus subtilis } & UCH FO11 \\
\hline
\end{tabular}

Table 2. Chemical composition of the leaf and stem essential oils of S. sparganophora.

\begin{tabular}{|c|c|c|c|}
\hline \multirow[b]{2}{*}{ Retentive index (RI) } & \multirow[b]{2}{*}{ Compound } & \multicolumn{2}{|c|}{$\%$ Composition } \\
\hline & & Leaf & Stem \\
\hline 865 & (E)-2-Hexanal & 2.3 & 3 \\
\hline 868 & 1-Hexanol & nil & $\operatorname{tr}$ \\
\hline 900 & n-Nonane & nil & 1.4 \\
\hline 902 & Heptanal & nil & 0.4 \\
\hline 926 & Tricyclene & 0.3 & nil \\
\hline 939 & $\alpha$-Pinene & nil & 0.4 \\
\hline 953 & Camphene & nil & $\operatorname{tr}$ \\
\hline 976 & sabinene & 0.3 & 1.1 \\
\hline 980 & $\beta$-pinene & 2.5 & 0.6 \\
\hline 985 & 6-Methyl-5-hepten-2-one & nil & $\operatorname{tr}$ \\
\hline 991 & Mycrene & 0.5 & $\operatorname{tr}$ \\
\hline 999 & Decane & 0.7 & nil \\
\hline 1003 & Octanal & $\operatorname{tr}$ & $\operatorname{tr}$ \\
\hline 1007 & E-3-hexanal acetate & 0.7 & 0.4 \\
\hline 1008 & 1-Hexyl acetete & 0.2 & nil \\
\hline 1011 & $\mathrm{p}$-3-Carene & nil & $\operatorname{tr}$ \\
\hline 1026 & Pseudocumene & 0.3 & nil \\
\hline 1028 & p-Cymene & $\operatorname{tr}$ & $\operatorname{tr}$ \\
\hline 1031 & Limonene & 1 & 0.9 \\
\hline 1035 & 1,8-Cineole & 1.9 & 0.7 \\
\hline 1060 & trans-decahydronaphthalene & nil & $\operatorname{tr}$ \\
\hline 1100 & n-Undecane & 0.3 & 1.2 \\
\hline 1103 & Nonanol & 1.1 & 1 \\
\hline 1106 & E-2-nonenal & $\operatorname{tr}$ & 1 \\
\hline 1181 & Naphtalene & $\operatorname{tr}$ & $\operatorname{tr}$ \\
\hline 1190 & Methylsalicylate & 12.3 & 31.7 \\
\hline 1199 & n-Dodecane & 0.4 & 0.6 \\
\hline 1206 & Decanal & 0.4 & 0.6 \\
\hline 1299 & n-Tridecane & $\operatorname{tr}$ & $\operatorname{tr}$ \\
\hline 1306 & Undecane & $\operatorname{tr}$ & $\operatorname{tr}$ \\
\hline 1316 & (E,E)-2-4-decadienal & nil & $\operatorname{tr}$ \\
\hline 1376 & $\alpha$-Coperene & 0.4 & $\operatorname{tr}$ \\
\hline 1385 & Geranyl acetate & nil & $\operatorname{tr}$ \\
\hline 1391 & $\beta$-Elemene & 0.7 & 0.6 \\
\hline 1399 & Cyperene & nil & $\operatorname{tr}$ \\
\hline 1400 & n-Tetradecane & 0.7 & 1.3 \\
\hline 1405 & Z-Caryophyllene & nil & $\operatorname{tr}$ \\
\hline
\end{tabular}




\section{Continued}

\begin{tabular}{|c|c|c|c|}
\hline 1408 & Dodecanal & nil & $\operatorname{tr}$ \\
\hline 1419 & $\beta$-Caryophyllene & 44.5 & 26.1 \\
\hline 1428 & E- $\alpha$-lonone & 0.3 & $\operatorname{tr}$ \\
\hline 1439 & Trans- $\alpha$-Bergamotene & nil & $\operatorname{tr}$ \\
\hline 1455 & $\alpha$-humulene & 5.6 & 4.2 \\
\hline 1461 & Alloaromadendrene & 0.7 & $\operatorname{tr}$ \\
\hline 1475 & $\beta$-Chamigrene & $\operatorname{tr}$ & 0.4 \\
\hline 1480 & Germacrene D & 2.9 & 1 \\
\hline 1485 & $\beta$-Selinene & 1 & 2.4 \\
\hline 1487 & (E)- $\beta$-ionone & 1.2 & nil \\
\hline 1492 & Valencene & nil & $\operatorname{tr}$ \\
\hline 1496 & $\alpha$-Selinene & 0.3 & $\operatorname{tr}$ \\
\hline 1500 & n-Pentadecane & 0.4 & 0.8 \\
\hline 1504 & Germacrene-A & 3.4 & 1.7 \\
\hline 1508 & (E,E)- $\alpha$-farnesene & nil & $\operatorname{tr}$ \\
\hline 1509 & $\beta$-Bisabolene & 1.7 & nil \\
\hline 1513 & Tridecanal & nil & 0.8 \\
\hline 1524 & d-Cadinene & $\operatorname{tr}$ & $\operatorname{tr}$ \\
\hline 1565 & Trans-nerolidol & $\operatorname{tr}$ & 0.7 \\
\hline 1582 & Caryophyllene oxide & 4.2 & 4.9 \\
\hline 1600 & n-Hexadecane & 0.4 & 1.6 \\
\hline 1608 & Humulene epoxide 11 & $\operatorname{tr}$ & nil \\
\hline 1652 & Bisabolol 11 & nil & 0.4 \\
\hline 1700 & n-Heptadecane & 0.3 & 0.4 \\
\hline 1719 & Pentadedecanal & 2.1 & nil \\
\hline 1800 & n-Octadecane & $\operatorname{tr}$ & 0.8 \\
\hline 1848 & Hexahydro-farnesylactone & $\operatorname{tr}$ & nil \\
\hline 1900 & n-Nonadecane & nil & 0.9 \\
\hline \multicolumn{2}{|c|}{$\operatorname{tr}=\operatorname{traces}$} & & \\
\hline
\end{tabular}

Table 3. Antibacterial activity of essential oil from the leaf after 24 hours $(\mathrm{mm} \pm \mathrm{SD})$.

\begin{tabular}{ccccc}
\hline & \multicolumn{2}{c}{ Essential oil (ppm) } & 100 & Gentamicine \\
\hline Microorganism & 10000 & 1000 & $10.3 \pm 0.82$ & $10 \mu \mathrm{g} / \mathrm{ml}$ \\
Salmonella typhi & $13.3 \pm 2.52$ & $11.7 \pm 2.52$ & nil & $11.2 \pm 3.0$ \\
P. aeruginosa & $11.7 \pm 3.06$ & $8.0 \pm 2.0$ & $10.0 \pm 0.0$ & $10.8 \pm 2.0$ \\
Proteus mirabilis & $14.3 \pm 2.55$ & $10.5 \pm 0.71$ & nil & $10.0 \pm 0.0$ \\
Bacillus cereus & $11.5 \pm 2.12$ & $10.5 \pm 0.71$ & nil & $10.8 \pm 2.0$ \\
Bacillus subtilis & $13.0 \pm 0.00$ & $10.0 \pm 0.0$ & $10.8 \pm 2.0$ \\
\hline
\end{tabular}

Table 4. Antibacterial activity of essential oil from the stem after 24 hours ( $\mathrm{mm} \pm \mathrm{SD})$.

\begin{tabular}{|c|c|c|c|c|}
\hline \multicolumn{4}{|c|}{ Essential oil (ppm) } & \multirow{2}{*}{$\begin{array}{c}\text { Gentamicin } \\
10 \mu \mathrm{g} / \mathrm{ml}\end{array}$} \\
\hline Microorganism & 10000 & 1000 & 100 & \\
\hline Salmonella typhi & $20.00 \pm 0.0$ & $18.5 \pm 2.12$ & nil & $16.8 \pm 2.0$ \\
\hline P. aeruginosa & $18.5 \pm 2.12$ & $18.0 \pm 0.6$ & nil & $15.8 \pm 2.0$ \\
\hline Proteus mirabilis & nil & nil & nil & $10.0 \pm 0.0$ \\
\hline Bacillus cereus & nil & nil & nil & $10.8 \pm 2.0$ \\
\hline Bacillus subtilis & nil & nil & nil & $10.8 \pm 2.0$ \\
\hline
\end{tabular}


against Salmonella typhi and Peseudomonas aeruginosa but had no activity against Bacillus subtilis. The activities of both oils were higher than that of the standard Gentamycin.

Asteraceae generally have antibacterial activity [22] [23]. The activity of essential oil is related to the composition of the oil [24], functional group and period of collection of the leaves [22].

The antibacterial activity exhibited by the essential oil from Struchium sparganophora could be attributed to the presence of $\beta$-caryophyllene, Germacrene $\mathrm{D}$, a-humulene, Caryophyllene oxide and 1,8-cineole which had been confirmed to have antibacterial activity [25] [26].

Components are listed in order of their elution from RTX-5 column. Linear retention indices (LRI) were calculated using a homologous series $\mathrm{C}_{6}-\mathrm{C}_{28}$ n-alkanes. Percentage was obtained by FID peak area normalization without the use of response factor values represent the average of three measurements, $n=3$. The masses (MS) were gotten by comparison of the MS with those of the computer mass libraries NIST 05 library, Wiley and Adams [13].

\section{Acknowlegments}

We hereby acknowledge the contribution of the Staff of Department of Chemistry, Faculty of Science, University of Ibadan toward the completion of this research work.

\section{References}

[1] Gentry, A.N. (1993) Tropical Forest Biodiversity and the Potential for New Medicinal Plants. In: Kinghorn, A.D and Balandrin, A.G., Eds., Human Medicinal Agents from Plants. American Chemical Society, Washington DC, 13-24. http://dx.doi.org/10.1021/bk-1993-0534.ch002

[2] Iwu, M.M., Ducan, A.R. and Okunji, C.O. (1999) New Antimicrobial of Plant Origin. ASHS Press, Alexandria, 457462.

[3] De Smet, P.A.G.M., Keller, K. and Hansel, R. (1993) Adverse Effects of Herbal Drugs. Springer Verlag, Berlin, 56.

[4] Burkill, H.M. (1985) The Useful Plants of Tropical Africa, Royal Botanic Gardens, Kew. 2nd Edition, Vol. 1, Families A-D, 479.

[5] Jakupovic, J., Zdero, C., Boeker, R., Warning, U., Bohlmann, F. and Jones, S.B. (1987) Cernocistifolide und andere sesquiterpine lactone aus Vernonia und verwandten Arten. Liebigs Annalen der Chemie, 111-123.

[6] Akah, P.A. and Ekekwe, R.R. (1995) Ethnopharmacology of Some Asteraceae Family Used in Nigeria Traditional Medicine. Fitoterapia, 66, 351-355.

[7] do Céu de Madureira, M., Paula Martins, A., Gomes, M., Paiva, J., Proença da Cunha, A. and do Rosário, V. (2002) Antimalarial Activity of Medicinal Plants Used in Traditional Medicine in S. Tomé and Príncipe Islands. Journal of Ethnopharmacology, 81, 23-29.

[8] Oboh, G. (2006) Nutritive Value, Antioxidant and Antimicrobial Properties of Struchium sparganophora Leaves. Journal of Medicinal Food, 9, 276-280. http://dx.doi.org/10.1089/jmf.2006.9.276

[9] Oboh, G., Raddatz, H. and Henle, T. (2008) Antioxidant Properties of Polar and Non Polar Extracts of Some Tropical Green Leafy Vegetables. Journal of the Science of Food and Agriculture, 88, 2486-2492. http://dx.doi.org/10.1002/jsfa.3367

[10] Eko, M.E., Eteng, M.U. and Eyong, E.U. (2008) Phytochemical Composition And Effect of Aqueous Extract of Struchium sparganophora (L) On Cockroach Crude Extract-Induced-Airway Inflammatory Responses in Wistar Rats. Global Journal of Pure and Applied Sciences, 14, 4-29.

[11] Jakupovic, J., Zdero, C., Boeker, R., Warning, U., Bohlmann, F. and Jones, S.B. (1987) Cernocistifolide und andere sesquiterpine lactone aus Vernonia und verwandten Arten. Liebigs Annalen der Chemie, 111-123.

[12] Kasim, L.S., Ferro, V.A., Odukoya, O.A., Drumond, A., Ukpo, G.E., Seidel, V., Gray, A.I. and Waigh, R. (2011) Antimicrobial Agents from the Leaf of Struchium sparganophora (Linn) Ktze Asteraceae. Journal of Microbiology and Antimicrobials, 3, 13-17.

[13] Adams, R.P. (2007) Identification of Essential Oil Components by Gaschromatography/Mass Spectrometry. Allured Publishing Corporation, Carol Stream, 8-34.

[14] Durodola, J.I. (1977) Antibacterial Property of Crude Extract from a Herbal Wound Healing Remedy-Ageratum conyzoides. Planta Medica, 32, 388-390. http://dx.doi.org/10.1055/s-0028-1097620

[15] Cheruiyot, K.R. and Olila Kateregga, D. (2009) In-Vitro Antibacterial Activity of Selected Medicinal Plants from Longisa Region of Bomet District, Kenya. African Health Science, 9, 42-46. 
[16] Abo, K.A. and Ashidi, A (1999) Antimicrobial Screening of Bridelia, Micantha, Alchomea cardifolia and Boerhavia diffusa. African Journal of Medicine \& Medical Sciences, 28, 3-4.

[17] Reeves, D.S., Phillips, I. and Williams, J.D. (1979) Laboratory Methods in Antimicrobial Chemotherapy, Longman Group Ltd., Edinburgh, 20.

[18] Albuqueque, M.R., Silveria, E.R., Uchoa, D.E.A., Lemos, T.L.G., Souza, E.B., Santiago, M.G. and Pessoa, O.D.L (2004) Chemical Composition and Larvacidal Activity of the Essential Oils from Eupatorium Betonicaeforme (DC) Baker (Asteraceae). Journal of Agric Food Chemistry, 52, 6708-6711. http://dx.doi.org/10.1021/jf0352881

[19] Mojab, F., Tabatabia, S.A., Naghdi-badi, H., Nichavar, B. and Ghadyani, F. (2007) Essential Oil of the Root of Tanacetum parthenium (L.) Schulz. Bip. (Asteraceae) from Iran. Iranian Journal of Pharmaceutical Research, 6, 291-293.

[20] Yang, Y., Zhu, S., Cia, X., Tang, L., Liu, D., Huang, J. and Zou, G. (2008) Chemical Composition and Antimicrobial Activity of Essential Oil of Cacalia tangtica (Maxim) Hand-Mazz. Frontiers of Biology in China, 3, 402-407. http://dx.doi.org/10.1007/s11515-008-0073-3

[21] Mikulasovo, M. and Vavarkove, S. (2009) Antimicrobial Effects of Essential Oil from Tanacetum vugare L. and Salvia officialis growing in Slovakia. Nova Biotechnologica, 9, 161-166.

[22] Mayekiso, B., Magwa, M.L. and Coopoosamy, R.M (2006) Variation in the Essential Oilconstituent of Pteronia incana (Asteraceae). African Journal of Biotechnology, 5, 1220-1226.

[23] Matasyoh, J.C., Kiplimi, J.J., Karubiu, N.M. and Hailstrocks, T.P. (2007) Chemical Composition and Antimicrobial Activity of Essential Oil of Tarchonanthus camphoratus. Food Chemistry, 101, 1183-1187. http://dx.doi.org/10.1016/j.foodchem.2006.03.021

[24] Satomayor, J.A., Martinez, R.M., Gracia, A.T. and Jordan, M.J. (2004) Thymus zygis subsp. Gracillus Watering Level Effect on Phytomass Production and Essential Oil Quality. Journal of Agric Food and Chemistry, 52, 5418-5424. http://dx.doi.org/10.1021/jf0496245

[25] Albuquerque, M.R., Lemos, T.L.G., Pessoa, O.D.L., Nunes, E.P., Nascimento, R.F. and Silveria, E.R. (2006) Chemical Composition of the Essential Oil from Vernonia scopiodes (Asteraceae). Flavor and Fragrance Journal, 22, 249-250. http://dx.doi.org/10.1002/ffj.1782

[26] Kardali, S., Cakir, A., Mavi, A., Kilic, H. and Yildrim, A. (2005) Screening of Chemical Composition, Antifungal and Antioxidant Activity of Essential Oils from Three Turkish Artemisia Species. Journal of Agric Food Chemical, 53, 1480. 